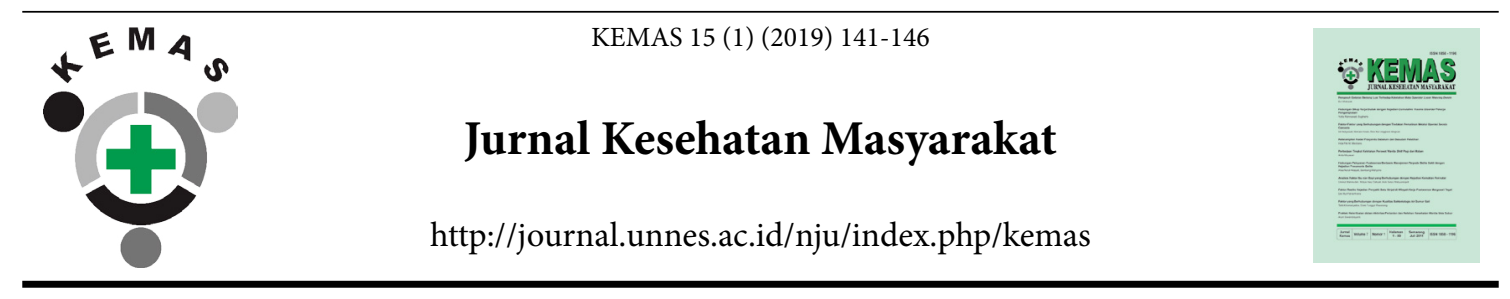

\title{
Proximate Determinant of Adolescents Fertility in Central Java
}

\author{
Bambang Budi Raharjo ${ }^{1 凶}$, Efa Nugroho ${ }^{1}$, Widya Hary Cahyati ${ }^{1}$, Najib ${ }^{2}$, Alfiana Ainun Nisa ${ }^{1}$ \\ ${ }^{1}$ Department of Public Health, Universitas Negeri Semarang, Indonesia. \\ ${ }^{2}$ National Population and Family Planning Board of Central Java, Indonesia.
}

\begin{tabular}{l} 
Article Info \\
\hline Article History: \\
Submitted April 2019 \\
Accepted June 2019 \\
Published July 2019 \\
\hline Keywords: \\
Environmental Health \\
Risk Analysis, Lead, \\
Riverside, Well water \\
\hline DOI \\
https://doi.org/10.15294/ \\
kemas.v15i1.21364
\end{tabular}

\begin{abstract}
Adolescent fertility is an important issue in terms of health and social care due to its relation to morbidity and mortality of mothers and children. The 2017 IDHS provided data regarding the percentage of women aged 15-19 who already became mothers or pregnant with their first child according to background characteristics. The 2017 IDHS results showed 7 percent of women aged 15-19 were mothers: 5 percent had given birth and 2 percent were pregnant with their first child. This study used a quantitative secondary data analysis approach. The secondary data used were the results of the Central Java IDHS 2017. The population of this study was all adolescent girls aged 15-19 years in Central Java. The unit analysis in the study were women of childbearing age which were 15-19 years from the analysis unit of Central Java IDHS in 2017 with a total sample of 4,560 respondents. From the results of the study, we noted that factors related to adolescent fertility in Central Java were age, education, use of contraception, marital status, status of living with a partner, and practice of sexual relations. Factors which were not related to adolescent fertility in Central Java were occupation, wealth, type of residential area, insurance ownership, duration of abstinence, partner's age, partner's level of education, and partner's occupation.
\end{abstract}

\section{Introduction}

The results of the 2017 Indonesian Demographic and Health Survey (IDHS) provided data regarding the percentage of women aged 15-19 years who became mothers or pregnant with their first child according to background characteristics. The 2017 IDHS results showed that 7 percent of women ages 15-19 were mothers: 5 percent had given birth and 2 percent were pregnant with their first child. The data showed that high number of adolescents already performed active sex, but they had low understanding of reproductive health. The percentage of female adolescents in rural areas who became mothers was much higher compared to those living in urban areas, which were $10 \%$ and $5 \%$ respectively. There was also an illustration of the trend of fertility in adolescents based on their level of education and wealth quintile level. The higher the level of education and wealth quintile, the lower the percentage of adolescents who became mothers. There were significant differences between women with an elementary education and below and women with a higher education and between women in the lowest wealth quintile $(13 \%)$ to the women in the highest wealth quintile $(2 \%)$.

The results of the IDHS showed that the trend of adolescent fertility in Indonesia was declined. In 1997, around $12.2 \%$ of adolescents had raised a family, 9.4\% had given birth to a 
child and $2.7 \%$ were pregnant with their first child. The 2002/2003 IDHS showed a decrease to $10.4 \%$ of adolescents who had given birth or were pregnant with their first child. In 2007, $6.6 \%$ of adolescents had given birth and $1.9 \%$ of adolescents were pregnant with their first child. Meanwhile, the 2012 IDHS results showed an increase in adolescent fertility, the percentage of female adolescents aged 15-19 who had given birth and became pregnant with their first child was $10 \%$.

Various local and international studies had shown that socio-demographic characteristics of adolescents had a relationship with adolescent fertility. For example, age, education and residence of adolescents were reported to have a close relationship with fertility. Education could influence fertility, because people who postponed their marriage (late marriage) had increased knowledge and access to effective methods of family planning and they also had the ability to make decisions on the number of children that they need. Meanwhile, other studies showed that educated adolescents were less likely to breastfeed their children compared to uneducated women, therefore it could affect fertility in the opposite direction. Other variables that had shown diverse effects on fertility were access to media, economic status, employment status, religion, and ethnicity.

This study was conducted to determine patterns and differences in adolescent fertility according to several variables and what factors affected adolescent fertility and how each factor influenced adolescent fertility in Indonesia.

Methods

This study used a quantitative approach of secondary data analysis. The secondary data were acquired from the results of the Central Java IDHS in 2017. The population of this study was all female adolescents aged 15-19 years in Central Java. The unit analysis in the study were women of childbearing age which were 15-19 years from the analysis unit of Central Java IDHS in 2017 with a total sample of 4,560 respondents. The range limit of analysis unit (15-19 years old) was based on the definition of adolescents according to the WHO.

The dependent variable in this study was the incidence of adolescent fertility, including whether adolescents had given birth or were pregnant with their first child. The independent variables in this study were education, work status, religion, number of died children, wealth quintile index. The intermediate variables in this study were the age of first sexual intercourse, number of marriages, contraception usage, menstruation after giving birth, the gap of sexual intercourse after delivery, and exclusive breastfeeding.

In general, fertility was defined as the ability to produce offspring which was associated with female fertility. Another notion of fertility was the ability of a wife to become pregnant and give birth to a living child by a husband who was able to impregnate her. Both definitions emphasize the birth of offspring or living children (Pratiwi and Herdayati, 2013). A woman's fertility level could be influenced by a variety of factors, including level of education, employment, income, perception of the value of children, infant / toddler mortality, unmet need, and age of first marriage (Pratiwi and Herdayati, 2013).

\section{Results and Discussion}

Relationship between Women's Age and Fertility

The relationship between women's age and fertility showed a positive relationship, i.e. the older the woman, the higher the birth rate were. The percentage of adolescent mothers aged $\leq 17$ years with children reached $0.9 \%$, while the percentage of mothers aged 18-24 years with children were only $7 \%$. From the Chi-square test it was concluded that there was a significant relationship $(\mathrm{p}<0.05)$ between age and adolescent fertility in Central Java.

Relationship between Education Level and Fertility

The relationship between education level and fertility showed a negative relationship. If the woman was in higher education, the fertility was lower. The percentage of adolescent mothers with elementary school degree who had children reached $0.9 \%$, while the percentage of adolescent mothers with higher education than elementary school education were only at $7 \%$. The effect of education on fertility was significant $(p<0.05)$, therefore it can be concluded that there was a relationship between the level of education with adolescent 
Table 1. Distribution of the percentage of women according to the socio-demographic characteristics and the number of children born alive, Central Java, 2017

\begin{tabular}{|c|c|c|c|c|c|}
\hline \multirow[t]{2}{*}{ Characteristics } & & \multicolumn{4}{|c|}{ Fertility } \\
\hline & & 0 & $\geq 1$ & $\mathrm{p}$ value & Total \\
\hline \multirow[t]{2}{*}{ Age } & $\leq 17$ y.o. & 317 & 3 & 0.0001 & 320 \\
\hline & 18-24 y.o. & 146 & 11 & & 157 \\
\hline \multirow[t]{2}{*}{ Education } & $\leq$ Elementary School & 19 & 3 & 0.002 & 22 \\
\hline & Elementary School Graduate & 444 & 11 & & 455 \\
\hline \multirow[t]{2}{*}{ Occupation } & Unemployed & 362 & 12 & 0.5 & 374 \\
\hline & Employed & 101 & 2 & & 103 \\
\hline \multirow[t]{3}{*}{ Wealth } & Poor & 52 & 2 & 0.355 & 54 \\
\hline & Moderate & 98 & 5 & & 103 \\
\hline & Rich & 313 & 7 & & 320 \\
\hline \multirow[t]{2}{*}{ Area of Residence } & Urban & 265 & 8 & 0.994 & 273 \\
\hline & Rural & 198 & 6 & & 204 \\
\hline \multirow[t]{2}{*}{ Use of Contraception } & No & 317 & 14 & 0.0001 & 331 \\
\hline & Yes & 96 & 1 & & 97 \\
\hline \multirow[t]{2}{*}{ Insurance ownership } & No & 185 & 4 & 0.391 & 189 \\
\hline & Yes & 278 & 10 & & 228 \\
\hline \multirow[t]{2}{*}{ Marital Status } & Single & 444 & 0 & 0.0001 & 331 \\
\hline & Married & 19 & 14 & & 97 \\
\hline \multirow[t]{2}{*}{ Live with Partner } & Yes & 16 & 9 & 0.041 & 25 \\
\hline & No & 3 & 5 & & 8 \\
\hline \multirow[t]{2}{*}{ Sexual Intercourse } & Never & 438 & 0 & 0.0001 & 444 \\
\hline & Yes & 25 & 14 & & 33 \\
\hline \multirow[t]{2}{*}{ Abstinence duration } & $\leq 1$ year & 5 & 3 & 0.236 & 8 \\
\hline & $>1$ years & 0 & 1 & & 1 \\
\hline \multirow[t]{2}{*}{ Partner's Age } & $18-25$ y.o. & 15 & 8 & 0.178 & 23 \\
\hline & $26-40$ y.o. & 4 & 6 & & 10 \\
\hline \multirow[t]{2}{*}{ Partner's Level of Education } & Elementary School & 6 & 4 & 0.853 & 10 \\
\hline & Junior High School & 13 & 10 & & 23 \\
\hline \multirow[t]{2}{*}{ Partner's Occupation } & Unemployed & 0 & 1 & 0.237 & 1 \\
\hline & Employed & 19 & 13 & & 32 \\
\hline
\end{tabular}

Source: IDHS Data, 2017

fertility in Central Java.

The Relationship between Insurance Ownership and Fertility

The percentage of adolescent mothers with children who had insurance was
$3.5 \%$, slightly higher than the percentage of adolescent mothers with children who did not have insurance $(2.1 \%)$. After analyzing with Chi-square it turned out that the value was not significant ( $p>0.05$ ), therefore it can 
be concluded that there was no relationship between insurance ownership and adolescent fertility in Central Java.

Relationship between Marital Status and Fertility

Marital status had a positive influence on fertility. Adolescent mothers who were married had a higher chance of having children compared to adolescent mothers who were not married. The percentage of married adolescent mothers who had children was $42.4 \%$, while the percentage of adolescent mothers who were not married and had children was $0 \%$. The Chi-square test showed significant results ( $\mathrm{p}$ $<0.05$ ), therefore it can be concluded that there was a relationship between marital status and adolescent fertility in Central Java.

Relationship between the Status of Partner Residence and Fertility

Partner residence status referred to whether the adolescents lives with their partner or not. The percentage of adolescent mothers who lived with their partners and had children was $36 \%$, while the percentage of adolescent mothers who did not live with their partners and had children was $62.5 \%$. There was a negative influence between the partner residence status and fertility i.e. adolescent mothers who lived with their partners were more likely to have children. From Chi-square test, the results showed significant results ( $p$ $<0.05$ ), therefore it can be concluded that there was a relationship between partner residence status and adolescent fertility in Central Java.

Relationship between Sexual Experience With Fertility

Sexual experience referred to whether an adolescent has had previous sexual intercourse experience or not. The number of adolescent mothers who have never had sexual relations and have children amounted to $0 \%$, while the number of adolescent mothers who had previous sexual intercourse and had children amounted to $35.9 \%$. There was a positive influence between the experience of sexual relationship with the possibility of having children in adolescents. Chi-square test showed significant results $(\mathrm{p}<0.05)$, therefore it can be concluded that there was a relationship between sexual experience with adolescent fertility in Central Java.
The Relationship of the Abstinence Duration and Fertility

Long time abstinence referred to how long an adolescent could abstain from sexual relationship. The duration of abstinence was divided into $<1$ year and $>1$ year. From Chisquare test, it was found that the results were not statistically significant ( $p>0.05$ ), therefore it can be concluded that there was no relationship between abstinence duration and adolescent fertility in Central Java.

Partner's age, partner's level of education, and partner's occupation did not have significant effects on adolescent fertility in Central Java ( $p>0.05)$.

From the data analysis, we found that there were significant relationships between fertility and age ( $\mathrm{p}$-value $=0.0001)$, and between fertility and education ( $\mathrm{p}$-value $=$ 0.002). The results showed that there was no relationship between fertility and employment ( $\mathrm{p}$-value $=0.5)$. This difference was due to the fact that Central Java was in the process of development. Many industrialization and factory construction take place in various areas. The development has implications in the increasing number of adolescents who worked as factory workers.

The proportion of women of childbearing age with children tend to increase from the lowest to the middle wealth quintile, then decreased when they reach the highest wealth quintile. The results showed that there was no relationship between fertility and wealth index $(\mathrm{p}$-value $=0.355)$.

The area of residence reflected the availability of access to community services, especially access to health services including family planning services. Access to health services for people in urban areas was assumed to be better than in rural areas. The results of the study showed that there was no relationship between fertility and the area of residence ( $p$-value $=0.994)$. Meanwhile, data analysis showed that there was a relationship between fertility and contraceptive use ( $\mathrm{p}$-value = 0.0001).

The survey results revealed that there was no relationship between fertility and health insurance ownership ( $p$-value $=0: 39)$. There were two types of care offered by insurance 
companies, namely hospitalization (in-patient treatment) and outpatient treatment. Health insurance products were produced by the social insurance company, life insurance company, and also a general insurance company.

There was a relationship between fertility and marital status ( $\mathrm{p}$-value $=0.0001$ ). The study showed that in terms of socio-cultural aspects, generally, adolescent (especially women) was afraid to become an unmarried woman and there was a pride when she was quickly proposed. This could cause a high rate of marriage at a young age. The young couple then wanted to have children immediately because most mothers in childbearing age had a positive perception of the value of children, such as to provide emotional linkage, economic benefits, self-development, harmony, and family successors.

Based on the results of the study, we found that there was a relationship between partner residence status with fertility ( $p$-value $=0.041)$. Couples who had long distance relationships tend to have higher desire to have children compared to couples who live in the same house.

Abstinence was the desire to abstain from sexual intercourse. Abstinence came in two ways, namely voluntary abstinence (postpartum, terminal, occasional, gestational, and menstrual) and forced abstinence (impotence, illness, temporary separation). The researcher divided the duration of abstinence in this study into two categories, namely $<1$ year and $\geq 1$ year. Based on the results of the study, we found that there was no relationship between the duration of abstinence ( $\mathrm{p}$-value = 0.236 ) with fertility.

Age of an individual was calculated from birth to their recent birthday. In this study, the age of the couple was divided into two categories, namely 18-25 years old and 26-40 years old. Based on the results of the study, we found that there was no relationship between partner's age $(p$-value $=0.178)$ and fertility.

We also found that there was no relationship between fertility and partner's level of education ( $\mathrm{p}$-value $=0.853$ ). Partner's level of education could affect fertility but it must be supported by other factors such as their age when married and economic status.
Lower education level lead to lower age in the first marriage and vice versa. A person's low education could be caused by poor economic condition. The economic situation of the family was what drives a person to get married early in the hope that it would ease the burden on the family. This showed that there was a tendency that higher partner's education level could lead to more disagreement with the decision of early marriage.

Partner's occupation was related to the decision to have children. In general, someone who works will have better financial ability compared to someone who is unemployed. However, partner's occupation could also cause the delay of the birth of the first child. From the results of the study we found that there was no relationship between fertility and partner's occupation ( $\mathrm{p}$-value $=0.237$ ).

\section{Conclusions}

The results of the study showed that factors which were related to adolescent fertility in Central Java were age, education, use of contraception, marital status, partner residence status, and sexual experience. Meanwhile, factors that were not related to adolescent fertility in Central Java were employment, wealth, area of residence, insurance ownership, duration of abstinence, partner's age, partner's education level, and partner's occupation.

\section{References}

Adioetomo, SM dan Samosir, OB. (2011). Dasardasar Demografi (edisi 2). Jakarta: Salemba.

Adioetomo, SM. (1980). Pola Fertilitas di Indonesia: Analisa Secara Umum, Jakarta: BPS dan Lembaga Demografi Fakultas Ekonomi Universitas Indonesia (LDFE UI).

Arikunto.S. (1996). Prosedur Penelitian: Satu Pendekatan Praktik, Jakarta: Penerbit Rineka Cipta.

Arsyad, SS., Nurhayati, S. (2016). Determinan Fertilitas di Indonesia, Jurnal Kependudukan Indonesia, Vol.11, No. 1, 1-14.

Badan Kependudukan dan Keluarga Berencana Nasional (BKKBN), Badan Pusat Statitik (BPS) dan ORC Macro. Laporan Survei Demografi dan Kesehatan Indonesia 2007, Calverton, Maryland, USA: ORC Macro; 2013.

Badan Perencanaan Pembangunan Nasional (BAPPENAS). Rencana Pembangunan Jangka Menengah Nasional (RPJMN) Tahun 2010-2014; Buku II Memperkuat Sinergi 
Antar Bidang Pembangunan; Buku II Sosial Budaya dan Kehidupan Beragama. Jakarta: Bappenas; 2010.

Badan Pusat Statistik (BPS), Badan Perencanaan Pembangunan Nasional (BAPPENAS), dan UNFPA Indonesia. Proyeksi Penduduk Indonesia (Indonesia Population Projection) 2000-2025, Jakarta: CV. Gading Komunikatama; 2005.

BKKBN, (2016). Tahun 2035, Remaja Perempuan Indonesia Capai Angka 22 Juta. https://www. bkkbn.go.id/.../bkkbn-tahun-2035-remajaperempuan-indonesia-capai-a...diakses

BKKBN. (1999). Tingkat dan Perkembangan Pemakaian Alat Kontrasepsi Menurut Parameter Demografi, Sosial, dan Ekonomi
Indonesia 1994-1997. Jakarta: BKKBN.

BKKBN. (2017). Survei Kependudukan, Keluarga Berencana, Kesehatan Reproduksi Remaja dan Pembangunan Keluarga di Kalangan Remaja Indonesia: Jakarta

Pratiwi, YP., Herdayati, M. (2014). Pengaruh Umur Kawin Pertama Terhadap Tingkat Fertilitas Wanita Usia Subur Di Provinsi Jawa Barat Tahun 2012, Analisis Lanjut Survei Demografi Kesehatan Indonesia 2012, Departemen Biostatistik dan Kependudukan, Universitas Indonesia, Depok. 